\title{
Biotechnology revolution from academic entrepreneurship to industrial: chemo- entrepreneurship
}

\begin{abstract}
In this study, we investigate the development of biotechnology from academic entrepreneurship to industrial entrepreneurship. Several factors were studied in order to explore their influence on evolution of Biotechnology in three different context such as United States, Europe area (Italy) for this case study. In the present work some flexible factors were considered due to its transferability to other fields of broad observations regarding entrepreneuring.
\end{abstract}

Keywords: biotechnology, academic entrepreneurship, international entrepreneurship
Volume 7 Issue 6 - 2018

\section{Razieh Sadraei,Vahid Jafari Sadeghi, Maryam}

Sadraei

University of Torino, Department of Chemistry and NIS Centre, Italy

Correspondence: Razieh Sadraei, University of Torino, Department of Chemistry and NIS Centre, Via P Giuria 7, 10125, Torino, Italy, Email r.sabraei I989@gmail.com

Received: July 01, 2017 | Published: November 28, 2018

\section{Introduction}

Starting in the 1980 s, changes to funding policies and new, emerging scientific fields have been challenging the traditional relationship between academia and industry to include the transfer of technology from universities. ${ }^{1}$ The challenge for biotechnology developers is to overcome the divide between research outcomes and market adoption.

Biotechnology's growth was accelerated by the policies of Reagan administration in regard to the transfer of technology from the academic sector to commercial sector. In 1982, for the first time, universities could take title to and could transfer to exclusive commercial rights to technologies developed under federal funding. For the industry, it overcame a severe limitation in the late 1970s only some 12,000 Ph.D.s were skilled at biotechnology, and the vast majority of these were entrenched in academia. For the start-up biotechnology entrepreneur, the early 1980s (and 1983 in particular) were an unprecedented era of capital availability. In any other era, with its surrounding circumstances, that expectation may not be workable.

Because biotechnology investments represented investments in research occurring at the molecular level, technical due diligence was difficult to verify, and there were no applicable valuation models at the outset of this industry. Thus, venture capitalists, investment bankers, and entrepreneurs dealt with almost totally unverifiable values. For the biotechnology entrepreneur, product opportunities may have stood in sharper relief than for electronics. ${ }^{2}$ The divide is in part due to the mission of technology transfer offices to focus on licensing IP, and the absence of interaction. ${ }^{3}$ The concept of the entrepreneur is problematic because by definition it aims to capture what is on the move and in a process of continuous change. ${ }^{4}$

\section{The many applications of biotechnologies}

Biotechnology is an area of science with enormous potential. Cooperation and Development (OECD, 1989), biotechnology is the use of scientific and engineering principles (based on microbiology, genetics, biochemistry, chemical and biochemical engineering) to transform materials using biological agents (such as microorganisms, enzymes, animal or vegetable cells) with the aim of producing goods and services (OECD, 1989). Pharmaceuticals, new diagnostic kits, foods, chemical compositions, and new therapeutic methods are some examples of the goods obtainable, and environmental control and the treatment of effluents are among the services obtainable. ${ }^{6,7}$ The use of biotechnology actually goes back thousands of years and can be considered to coincide with the beginning of agriculture: biotechnological type processes are used to obtain products known since ancient times, such as beer (produced by the fermentation of grains), yogurt and wine, just to name a few. In order to better understand the many uses of biological technologies made throughout history, the OECD has classified biotechnologies into three categories: Traditional biotechnologies, which are thousands of years old, such as fermentation; Modern biotechnologies, which were developed after the industrial revolution, such as the biological processes used to obtain vaccines, enzymes and hybrids; New biotechnologies, which have been developed since 1970, thanks to the discovery of DNA recombination and cell fusion. ${ }^{6}$

\section{The development of biotechnologies in the United States and Europe including Italy}

The pioneering country was the United States where, starting from the early 1980s, small biotechnology companies (New Biotechnology Firms or NBFs) started up which developed the knowledge made available by genetic engineering and often made 'findings' that could have industrial applications. They are actually small research companies offering particular services or working, for example, on the production of a certain protein or the discovery of a new pharmaceutical. They are usually unable to complete the whole innovative process and therefore they set up collaborative relationships with larger companies (Established Companies or ECs) and supply their own output to these companies. The American biotechnology industry is a real network made up of universities, public and private research centers, small biotechnological companies and large con- solidated companies all working in collaboration rather 
than competition. The small companies are the real liaison between the academic world and the industrial world since they join 'the scientific community (depository of knowledge) and the technological community (geared towards taking advantage of scientific knowledge for industrial use). In fact, most of these companies started up with the help of universities and their founders often continue to maintain close relationships with academic research institutes. ${ }^{6}$

Biotechnologies represent one of the most significant emerging technologies, whose different applications can be used for the growth of knowledge-based industry. ${ }^{8}$ Even though there is a strong tradition of research in the pharmaceutical, chemical and food industries in Italy, the diffusion of the applications offered by biological technologies started taking place in Italy much later than in the United States and other European countries. This has led some experts to maintain that Italy has already missed the 'train of biotechnologies' (OPES, 2001). There are normative, institutional, cultural, and financial reasons for the late start of the development of the biotechnology industry in Italy. As far as the institutional aspect is concerned, in our country, as opposed to what has happened in other European countries (e.g. Germany), there has been a total lack of policies specifically aimed at supporting both research in the field of biotechnology and the industrial development of these technologies. In fact, the initiatives carried out by the Italian State can be summed up in a series of programs (e.g. Piano Biotecnologie Applicate per la Ricerca Avanzata and Programma Biotecnologie e Biostrumentazione) managed mostly by the academic world and, therefore, actually quite detached from the industry. There has basically been no process of knowledge transfer from universities to industries and, consequently, the phenomenon of academic spin offs, which is so widespread in the United States, has not taken place in Italy. ${ }^{5}$

The normative system has not helped improve this situation either, e.g. the complicated and often excessively bureaucratic norms which regulate the relationships between academic institutions and the industry and the limited protection guaranteed by patents. In addition to these difficulties, there is also the problem of finding venture capital. In fact, in Italy there is no structured system of venture capital which makes it possible to supply the financial resources needed to support the setting up of start up companies and the growth of the biotechnology industry segment in general. Therefore, even though there is a good level of scientific-technological knowledge and competencies in Italy (Gambardella, 1996), above all in the pharmaceutical field, there have been very few small startups specialized in biotechnologies. In fact, it is the general opinion of academics that in Italy biotechnologies and their applications are mostly developed in large consolidated companies (ECs) and public research centers (Orsenigo, 2001). ${ }^{5,9} \mathrm{It}$ has been estimated, with a low margin of error, that there are about 100 biotechnology companies in Italy. ${ }^{5}$

\section{Entrepreneurship}

Entrepreneurship starts with an idea or vision, occurring along a spectrum beginning at incremental improvement of an existing product or service, to a new revolutionary technology that disrupts an existing industry. ${ }^{10}$

\section{Role of universities in supporting academic entrepreneurship}

The general mission of an academic institution is twofold: to advance scientific knowledge and to share this knowledge for the benefit of the society. This latter ambition typically comes in the form of training students who then spread out into different sectors hosting conferences, consulting and collaborating with public and private interests, and publishing research results. Often overlooked is the intellectual property (IP) patented by academicians and licensed to private industry, a form of information transfer that can have significant societal and economic impact (4). This arrangement can have numerous beneficiaries; principals, and shareholders benefit from the direct financial success of the product, while researchers see wider and more rapid adoption of their ideas (5) and concomitant academic recognition. ${ }^{11}$

Entrepreneurship starts with an idea or vision, occurring along a spectrum beginning at incremental improvement of an existing product or service, to a new revolutionary technology that disrupts an existing industry. ${ }^{12}$ Academic entrepreneurship refers to university researchers commercializing university research through new business enterprises (Figure 1). ${ }^{13}$

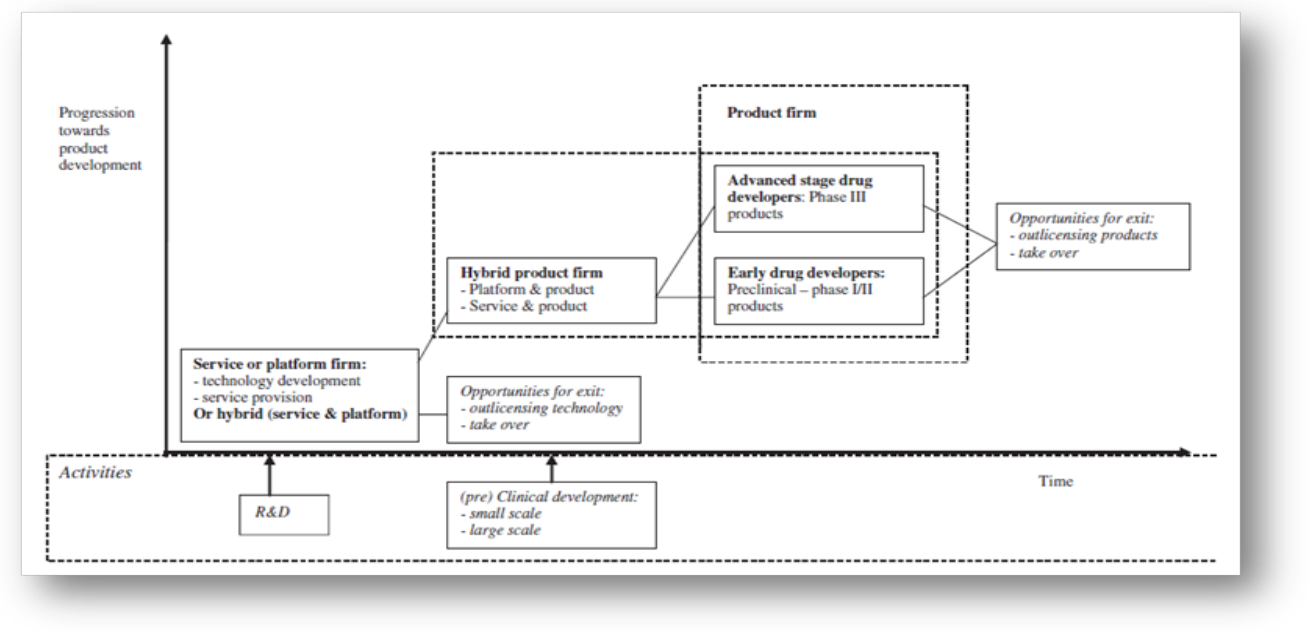

Figure I Possible sequence in business models of individual dedicated biotechnology firms. 


\section{International entrepreneurship (IE)}

Research in the fields of entrepreneurship and international entrepreneurship has experienced explosive growth recently. International Entrepreneurship can be divided into three major types of IE research:

a) Entrepreneurial Internationalization,

b) International Comparisons of Entrepreneurship and

c) Comparative Entrepreneurial Internationalization.

Type A research includes thematic areas in which the primary focus of each paper is concerned with: Venture Type, Internationalization, Networks and Social Capital, Organizational Issues and Entrepreneurship. Type B research has three main thematic areas consisting of Cross-Country and Cross-Cultural comparisons of entrepreneurship and studies which compare both. Type C research is the most recent to emerge and consists of studies that compare entrepreneurial internationalization across countries or cultures. ${ }^{13,14}$

\section{Business model' for Biotech entrepreneurship}

The term 'business model' is an abstract term. Some authors that studied biotechnology firms, for example Lim (2003) and Pavlou and Belsey (2005), discerned different types of business models but did not define the general term. Chesbrough and Rosenbloom (2002) did develop a useful definition of the business model, although not specific for biotechnology firms. According to them, the business model describes how the firm plans to make money and specifies the position of the firm in the value chain (Chesbrough and Rosenbloom, 2002). This definition implies that the activities a firm is engaged in are embedded in its business model. This portfolio of activities is, by definition, broader than just the main revenue generating activities of a firm. The business model of a firm does, however, provide an indication of the expected main revenue generating activities of the firm in the future. The choice for a specific business model is an important strategic choice, as firms can use it to position themselves within an industry. ${ }^{15} \mathrm{~L}$. Willemstein and her colleagues worked on business models of Dutch dedicated biotechnology firms (DBFs) that are active in the field of medical biotechnology. ${ }^{15}$

\section{Limiting factors on Biotech entrepreneur}

\section{A Different breed}

The biotech entrepreneur is unique from all other entrepreneurs. The biotech entrepreneur must still possess the same attributes all other entrepreneurs do; those being independence, confidence, a desire to take the road less traveled, a passion for their work, the ability to work long hours, unrelenting persistence, and willingness to take risks. In addition, the biotech entrepreneur is usually an accomplished scientist, bioengineer, physician, or businessperson. Most often, but not always, they have a $\mathrm{PhD}, \mathrm{MD}, \mathrm{MBA}$, or combination of these educational backgrounds. A biotech entrepreneur voluntarily leaves their comfortable world, and steps into an industry that carries uncertainties and risks unique to any other business. A biotech entrepreneur recognizes problems, but does not focus on them for long. This is strength of the biotech entrepreneur - but it can also be their downfall if not moderated. ${ }^{16}$

\section{Know the challenges: count the costs}

There are many challenges that await the entrepreneur. A biotechnology. ${ }^{17}$ company is a melding of business and science, and thus it creates a business of scientific uncertainty. The product development process contains unpredictable biological and technical risks. These risks arise from a core technology based upon promising yet unproven science. Entrepreneurs must be prepared for an extraordinarily long product development timeframe.

For the biotech entrepreneur, these risks are in addition to ones all entrepreneurs in any business face, such as overstretched operational capacities, new market development issues, and challenges recruiting quality people, to name a few. By stepping into the shoes of a biotech entrepreneur, the magnitude and number of obstacles surpass those all other entrepreneurs face. ${ }^{17}$ Before undertaking a start-up biotechnology company, one should count the costs because the stakes are exceedingly high. By understanding the challenges before beginning, one will be better prepared to handle them when they arise. Many individuals seek to accomplish lofty goals, but when things get tough, their desire wanes. Accomplishing anything of great value requires a significant amount of time and effort. The amount of time and effort is proportional to the significance of the endeavor. ${ }^{17,18}$

\section{Personal costs}

It is equally important to recognize the personal and family costs before starting down this path. The biotech entrepreneur should have a strong support system of family and close friends because their work will also impact these individuals. A support system is vital, because there will be times when their understanding, encouragement, and help (possibly even their money) is needed. ${ }^{16}$ Likewise in Europe, companies were founded around prestigious scientific institutions, such as the University of Cambridge, UK, which provided the academic background to establish biotech startups and spinoffs engaging researchers as founders. ${ }^{19}$

\section{Four backgrounds of Biotech entrepreneurs}

Academic entrepreneurship is a process in which a university professor starts a new firm to turn his1 breakthrough scientific discovery into commercially viable products. ${ }^{2}$ The form and function of firms' scientific advisory boards and the responsibilities and benefits of the members of these boards, however, receive much less research attention.

The typical biotech entrepreneur who starts a company usually comes from one of four background types. Although individuals from any background can start a biotechnology company - so long as they have the ideas, skills, and motivation. Unfortunately, the odds for success are heavily weighed against anyone not from one of these categories. Each of these backgrounds comes with their own strengths and weaknesses. The four most common backgrounds of life science entrepreneurs include the following:

1. The Scientist/Physician/Bioengineer who comes from an academic institution (University, Research Foundation, Nonprofit Research Institute)

2. The Scientist/Physician/Bioengineer who comes from within the life science industry such as another biotechnology company

3. A Businessperson, such as a former executive in the life science, pharmaceutical or venture capital industry, who is not a Scientist/Physician/Bioengineer

4. A Core Group of Individuals that are spun off from another life science organization within the industry. ${ }^{16,20}$ 


\section{For the scientist: things vs. People}

The largest majority of biotech entrepreneurs come from a scientific background, and this influences the things to which they gravitate. Fundamentally, a large percentage of scientists become scientists because they either enjoy or are more comfortable working with "things" (experiments) rather than "people." This does not imply that scientists do not like people; it is just that they find the challenges and rewards of research more fulfilling, compared to the challenges and rewards of predominantly working with people. Ironically, a significant part of a biotech entrepreneur's job requires that they work more with people rather than with experiments and science. As with any job there are skills that must be acquired in order to do what needs to be done whether one enjoys it or not.

\section{For the businessperson: communication with scientists}

The entrepreneur with an entirely business background has a different challenge to wrestle with than does the scientist. Individuals with business backgrounds have a difficult time appreciating the technical challenges of the science, and typically have trouble understanding why technology development takes so long. This gap can be disastrous for planning. Most businesspersons do not have the background to readily understand the limitations of a technology; as a result, they may be surprised by "unplanned" scientific problems, resulting in product development delays that translate into financial shortfalls. To them, it may not seem obvious why a scientist cannot just run an experiment once, get the results, and move on. It is critical that the businessperson learn as much as possible about scientific issues by asking questions of the scientists to gain appreciation of the technology and its limitations.

\section{First time entrepreneur, first time in business}

\section{Alternatives to consider before taking the leadership role}

If a professor, physician, scientist, or bioengineer from an academic background is contemplating starting a biotechnology company, but unsure about the decision to lead the company, they may want to consider a few alternatives. There are several ways to participate in the entrepreneurial process without carrying the responsibility for the entire organization and its outcome. Each of these alternatives still provides valuable experience for participating in the entrepreneurial process and equips you better for a future entrepreneurial opportunity. Options include:

1. Take the position of Chief Scientific Officer or Chief Medical Officer in the new company and allow someone else more experienced to shoulder the major business and financing responsibilities for the organization.

2. Participate as a cofounder in getting the company started and then return to research or medical practice, while contributing in a role as a Scientific Advisory Board Member or Board Member.

3. Be the scientific founder, help establish the company, and possibly work to get seed funding with the idea of later recruiting an experienced CEO. Find out how well you do before deciding whether or not to continue in this role, or turn it over to someone with more experience.

\section{Passion and vision}

The most successful biotech entrepreneurs all possess these two components - they have a vision and passion about what they are doing. Entrepreneurial passion is not an emotional characteristic, but a driving desire to accomplish something they firmly believe in, and will do, no matter how difficult the challenge. Being a visionary is about:

\section{Seeing something others don't see}

2. Communicating what they see in a way that inspires others to follow

Entrepreneurs should be sure they possess these characteristics if they are going to start a biotech company, because they will need them when they face the many challenges during company development. Also, potential investors will be looking for these characteristics because they know that they are essential to building a successful company. ${ }^{16}$

\section{Learn new skills quickly}

Regardless of how accomplished someone may be in their present career, they should not be fooled into believing this guarantees success as a biotech entrepreneur. Entrepreneurs need to learn new skills quickly or they will not be successful. ${ }^{16}$

\section{Have the ability to speak two languages}

\section{Be a Multi-disciplined translator}

A significant universal barrier to achieving success for a biotechnology company is the absence of a "multi-disciplined translator". A multi-disciplined translator is a person who understands the marketing, financial, and business issues, but also understands the technical and scientific issues - and speaks both languages well. One of two scenarios is usually played out in biotech start-up organizations: The first, is where the entrepreneur without a technical background, cannot or does not want to understand the scientific issues and limitations. In this situation, the entrepreneur operates in a pseudo-environment where they believe the science operates in a certain way, but in reality it does not. The second situation is where the entrepreneur is a scientist who cannot, or will not, learn to communicate scientific issues in a way that the business and financial persons and investors can understand. They tend to go headlong into a discourse on issues that are of no interest to anyone except those with a technical mind. ${ }^{16}$

\section{Be a negotiator}

This may sound like an unusual topic for a biotech entrepreneur.

\section{Enlarge your circle of influence}

It is important for a biotech entrepreneur to build a circle of influence by including many people they trust - these will be individuals from whom they can later seek help, advice, and assistance. ${ }^{16}$

\section{On creativity and change}

One of the strengths of a start-up biotechnology company is their ability to respond quickly to change. The biotech entrepreneur's ability to respond to change is critical to the future success of the organization. ${ }^{16}$

\section{Summary}

Successful entrepreneurs possess a diverse list of characteristics 
that add significance at various stages of their biotech career. They are multi-taskers, or as one serial entrepreneur put it - they must have "rapidly adaptive, serial, single-pointed, focused attention." First time entrepreneurs who have started and built companies will point out that the qualities described herein are ones they all wish they had a good dose of early in their tenure. A biotech entrepreneur may not initially possess every skill required to lead a talented and diverse team to build a successful business, however, as with any skill set, most can be learned if the entrepreneur is willing. Once these skill sets are acquired and proficiency is gained, these entrepreneurs generally go on to start many other biotech companies. These serial entrepreneurs successively build upon each previous learning experience and become proficient at their work and at recognizing the critical components of a successful business opportunity.

Whether someone seeks to start or join a company at any stage of development, a good analogy for building a biotech company is to realize that every great architectural structure we see today was first conceived in someone's mind. The Eiffel Tower was just a concept - a grand idea that existed many years before the first steel girder was ever set in place. During its inception, the visionaries encountered seemingly insurmountable challenges, and were faced with many reasons to quit. Some of the naysayers of this project voiced that it costs too much, the design cannot support its weight, and the land where it is to be erected is not solid. Through the perseverance of the Tower's visionaries and their ability to communicate the vision effectively to others - they recruited a team that later solved the engineering, construction, financing, and political challenges. As a result, this monumental piece of architecture stands today. What is your vision? Communicate it frequently to others, and before you know it you will see a company established and growing through the efforts of diverse individuals, all joined together to accomplish something far greater than anyone can accomplish alone.

It will thus be of use to individuals with interests, both commercial and academic, in areas of applied biotechnology and biochemistry.

The academic literature offers plenty of evidence that innovation and entrepreneurship are strongly correlated to economic growth. Moreover, regions with high levels of research and development, patents, start-ups, and venture capital develop faster than other areas. The missing link for many regions is the component of entrepreneurship; it is the entrepreneur who brings fresh ideas forward, commercializes these innovations, and brings them to market. ${ }^{21}$

\section{Acknowledgments}

None

\section{Conflicts of interest}

Author declares that there is no conflicts of interest.

\section{References}

1. Wurmseher M. To each his own: Matching different entrepreneurial models to the academic scientist's individual needs. Technovation. 2017:1-17.

2. Zhan Q. Integration of genomic science and personalized cancer Journal of Biotechnology. 2010;150:551-552.

3. Ding W, Choi E. Divergent paths to commercial science: A comparison of scientists' founding and advising activities. Research Policy. 2011;40(1):69-80.
4. Styhre A. Transduction and entrepreneurship: A biophilosophical image of the entrepreneur. Scandinavian Journal of Management. 2008;24(2):103-112.

5. Knill CJ, Kennedy JF. Biotechnological Avenues for Entrepreneurship Development-A Compendium-Focus: Women and Rural Development. Carbohydrate Polymers. 2003;54(3):391.

6. Nosella A, Petroni G, Verbano C. Characteristics of the Italian biotechnology industry and new business models: The initial results of an empirical study. Technovation. 2005;25(8):841-855.

7. Pipirigeanu M, Gheorghe Zaman, Horatiu Strasser. Academic Entrepreneurship and Scientific Innovation in Context of Bio-economy Strategy. Procedia Economics and Finance. 2014;8(14):556-562.

8. Bigliardi B, Nosella A, Verbano C. Business models in Italian biotechnology industry: A quantitative analysis. Technovation. 2005;25(11):1299-1306.

9. Morselli D, Costa M, Margiotta U. Entrepreneurship education based on the Change Laboratory. International Journal of Management Education. 2014;12(3):333-348.

10. Lexa FJ. Medical entrepreneurism: The current opportunity in America. J Am Coll Radiol. 2004;1(10):762-768.

11. Itri JN. Entrepreneurship in the Academic Radiology Environment. Academic Radiology. 2015;22(1):14-24.

12. Cantu Ortiz FJ. Spreading academic entrepreneurship: Made in Mexico. Business Horizons. 2017;60(4):541-550.

13. Awaysheh A, Bonfiglio D. Leveraging experiential learning to incorporate social entrepreneurship in MBA programs: A case study. The International Journal of Management Education. 2017;15(2):332349.

14. Dimitratos P. International entrepreneurial culture-Toward a comprehensive opportunity-based operationalization of international entrepreneurship. International Business Review. 2012;21(4):708-721.

15. Willemstein L, Van der Valk T, Meeus MTH. Dynamics in business models: An empirical analysis of medical biotechnology firms in the Netherlands. Technovation. 2007;27(4):221-232.

16. Shimasaki CD. The business of bioscience: What goes into making a biotechnology product. The Business of Bioscience: What goes into Making a Biotechnology Product. 2009;1-269.

17. Adams KR, Brennant M. Introducing Business and Biochemistry Curriculum Enterprise into the. Biochemical Education. 1994;3(22):135-137.

18. Gassmann O, Keupp MM. The competitive advantage of early and rapidly internationalising SMEs in the biotechnology industry: A knowledge-based view. Journal of World Business. 2007;42(3):350 366.

19. Medina Molotla N. Some factors limiting transfer of biotechnology research for health care at Cinvestav: A Mexican scientific center. Technology in Society. 2017;(48):1-10.

20. Paristiowati M, Slamet R, Sebastian R. Chemo-entrepreneurship: Learning Approach for Improving Student's Cooperation and Communication (Case Study at Secondary School, Jakarta). ProcediaSocial and Behavioral Sciences. 2015;174:1723-1730.

21. Ziona Austrian, Merissa C Piazza. Barriers and opportunities for entrepreneurship in older industrial regions. The Road Through the Rust Belt: From Preeminence to Decline to Prosperity. 2014;9:215-243. 